\title{
Effects of autologous bone marrow stem cell transplantation on beta-adrenoceptor density and electrical activation pattern in a rabbit model of non-ischemic heart failure Stefan Dhein ${ }^{* 11}$, Jens Garbade ${ }^{\dagger 1}$, Djazia Rouabah ${ }^{1}$, Getu Abraham², Fritz- Rupert Ungemach ${ }^{2}$, Katja Schneider ${ }^{1}$, Cris Ullmann ${ }^{1}$, Heike Aupperle ${ }^{3}$, Jan Fritz Gummert ${ }^{1}$ and Friedrich-Wilhelm Mohr ${ }^{1}$
}

Address: ${ }^{1}$ Clinic for Cardiac Surgery, Heart Centre Leipzig, University of Leipzig, Germany, ${ }^{2}$ Institute for Pharmacology, Pharmacy and Toxicology, Faculty of Veterinary Medicine, University of Leipzig, Germany and ${ }^{3}$ Institute of Veterinary Pathology, University of Leipzig, Faculty of Veterinary Medicine, Germany

Email: Stefan Dhein* - dhes@medizin.uni-leipzig.de; Jens Garbade - jgmed93@hotmail.com; Djazia Rouabah - djazia@web.de; Getu Abraham - gabraham@rz.uni-leipzig.de; Fritz-Rupert Ungemach - ungemach@rz.uni-leipzig.de; Katja Schneider - schneiderle@web.de; Cris Ullmann - cris.ullmann@t-online.de; Heike Aupperle - aupperle@rz.uni-leipzig.de; Jan Fritz Gummert - gumj@medizin.uni-leipzig.de; Friedrich-Wilhelm Mohr - mohrf@medizin.uni-leipzig.de

* Corresponding author †Equal contributors

Published: 26 June 2006

Journal of Cardiothoracic Surgery 2006, I:17 doi:10.1186/1749-8090-I-17
Received: II April 2006

Accepted: 26 June 2006

This article is available from: http://www.cardiothoracicsurgery.org/content/I/I/I7

(C) 2006 Dhein et al; licensee BioMed Central Ltd.

This is an Open Access article distributed under the terms of the Creative Commons Attribution License (http://creativecommons.org/licenses/by/2.0), which permits unrestricted use, distribution, and reproduction in any medium, provided the original work is properly cited.

\begin{abstract}
Background: Since only little is known on stem cell therapy in non-ischemic heart failure we wanted to know whether a long-term improvement of cardiac function in non-ischemic heart failure can be achieved by stem cell transplantation.

Methods: White male New Zealand rabbits were treated with doxorubicine ( $3 \mathrm{mg} / \mathrm{kg} /$ week; 6 weeks) to induce dilative non-ischemic cardiomyopathy. Thereafter, we obtained autologous bone marrow stem cells (BMSC) and injected I.5-2.0 Mio cells in I ml medium by infiltrating the myocardium via a left anterolateral thoracotomy in comparison to sham-operated rabbits. 4 weeks later intracardiac contractility was determined in-vivo using a Millar catheter. Thereafter, the heart was excised and processed for radioligand binding assays to detect $\beta_{1}$ - and $\beta_{2}$-adrenoceptor density. In addition, catecholamine plasma levels were determined via HPLC. In a subgroup we investigated cardiac electrophysiology by use of 256 channel mapping.

Results: In doxorubicine-treated animals $\beta$-adrenoceptor density was significantly down-regulated in left ventricle and septum, but not in right ventricle, thereby indicating a typical left ventricular heart failure. Shamoperated rabbits exhibited the same down-regulation. In contrast, BMSC transplantation led to significantly less $\beta$-adrenoceptor down-regulation in septum and left ventricle. Cardiac contractility was significantly decreased in heart failure and sham-operated rabbits, but was significantly higher in BMSC-transplanted hearts. Norepinephrine and epinephrine plasma levels were enhanced in heart failure and sham-operated animals, while these were not different from normal in BMSC-transplanted animals. Electrophysiological mapping revealed unaltered electrophysiology and did not show signs of arrhythmogeneity.
\end{abstract}

Conclusion: BMSC transplantation improves sympathoadrenal dysregualtion in non-ischemic heart failure. 


\section{Background}

Stem cell transplantation, in particular transplantation of mesenchymal autologous bone marrow stem cells, is currently discussed to be a possible alternative to heart transplantation and may be of therapeutic interest in ischemic heart disease [1-3]. The use of autologous bone marrow stem cells (BMSC) has the advantage of non-immunogeneity. Until now there are a number of experimental [4-6] and also clinical [7-11] studies demonstrating positive effects of stem cell therapy in ischemic heart disease. However, at present there is only little knowledge on the use of autologous stem cells in non-ischemic cardiomyopathy. Thus, we decided to investigate the effect of autologous bone marrow stem cell transplantation in doxorubicineinduced non-ischemic cardiomyopathy in rabbits using direct epicardial infiltration for delivery.

A special problem with the evaluation of such a therapy is to get an impression of the long-term improvement in hemodynamics and in the sympathoadrenal regulation. Thus, echocardiography and related methods give a measure for the acute contractility at the moment of investigation, but do not allow an insight into the sympathoadrenal dysregulation typical for heart failure [12] or its possible normalisation by therapy. The idea of our study was to assess the effect of BMSC transplantation therapy on non-ischemic heart failure by measurement of contractility and $\beta$-adrenoceptor density using (-)-125 [I ]iodocyanopindolol radioligand binding assay: it is long known that heart failure leads to compensatory activation of sympathoadrenal system with enhanced release of catecholamines and to down-regulation of cardiac $\beta_{1}$-adrenoceptors $[13,14]$, which is correlated to the severity of the disease $[15,16]$, affecting mostly $\beta_{1}$-adrenoceptors while $\beta_{2}$-adrenoceptors remained unaltered in most studies [17] and finally resulting in a decrease in $\beta$-adrenoceptor density. Remaining $\beta$-adrenoceptors are desensitized, probably mostly via G-protein coupled receptor kinases (GRK2 and/or GRK5) [17-22] and to some extent via pathways involving PKA [23]. The down-regulation of $\beta$-adrenoceptor number as assessed via radioligand binding studies mirrors the severity of chronic heart failure [14]. This holds also true for rabbits suffering from chronic heart failure [24].

Treatment of chronic heart failure with the $\beta$-blocker metoprolol results in hemodynamic improvement and up-regulation of $\beta$-adrenoceptor density $[25,26]$. The process of $\beta$-adrenoceptor down-regulation in chronic heart failure takes days to weeks and the extent of this reduction in $\beta$-adrenoceptor number is directly related to the severity of heart failure $[13,14,27]$, thus, reflecting the long-term hemodynamic situation. Inversely, an effective therapy of heart failure should lead to better contractility and in consequence a reduction of heart failure-induced enhancement in catecholamine levels and finally a (partial) normalisation of $\beta$-adrenoceptor density. Therefore, we decided to measure $\beta$-adrenoceptor density, contractility and catecholamine levels in normal rabbits, doxorubicine-induced non-ischemic cardiomyopathy with or without autologous BMSC transplantation or sham-operation.

\section{Methods}

The study was performed in accordance to the German laws for animal health and protection declaration and was approved by the local authorities, Government of Leipzig (Reg.-Nr.: 24-9168.11-11/03). We used male White New Zealand rabbits of 1500-2000 g body weight (at beginning of the study) (conventional, normally fed ad libitum) (Charles River, Kisslegg, Germany).

\section{Animal model and investigation of contractility}

Heart failure was induced by repeated i.v. injection of doxorubicine $3 \mathrm{mg} / \mathrm{kg} /$ week over 6 weeks, followed by a 14 days doxorubicine-free interval. Animals that survived 2 weeks after heart failure induction were randomized to either no treatment, sham operation or BMSC transplantation. After intramuscular anaesthesia with ketamin (50 $\mathrm{mg} / \mathrm{kg}$ ) and xylazine (5 mg/kg), we obtained autologous mesenchymal bone marrow stem cells from a femur punction, isolated the mononuclear stem cell fraction, and after subcultivation for 4 days (see below), the stem cells were injected directly into the wall of the left ventricle. For transplantation rabbits were anaestetized ( 0.8 vol\% isofluran, protocol see [28]. Left thoracotomy through the intercostal space was performed and the left ventricle was exposed. Either BMSC (1.5 - 2.0 Mio cells in $1 \mathrm{ml})$ or medium ( $1 \mathrm{ml}$ ) was injected at 4 positions into the tissue of the free lateral wall of the left ventricle in a circular manner with a $1 \mathrm{ml}$ syringe within 2 minutes.

28 days after the operation, animals were subjected to the final experiment. One hour prior to surgery (anaesthesia as described above), we collected $2 \mathrm{ml}$ venous blood in potassium EDTA monovettes (with addition of $1 \mu \mathrm{M}$ glutathione/ml plasma) from the rabbits after at least $30 \mathrm{~min}$ at rest for determination of plasma catecholamines. After centrifugation $\left(600 \mathrm{~g} / 10 \mathrm{~min} / 4^{\circ} \mathrm{C}\right)$, plasma was removed, quickly frozen in liquid nitrogen, and stored at $-80^{\circ} \mathrm{C}$ until further use. We introduced a Millar catheter designed for rabbits (FMI, Germany) via the femoral artery and registered pressure-volume loops under the influence of 1.5 $\mu \mathrm{g} / \mathrm{kg}$ dopamine, in order to assess the contractile function. $\mathrm{dP} / \mathrm{dt}_{\max }$ and $\mathrm{dP} / \mathrm{dt}_{\min }$ were determined from these measurements. Subsequently, we excised the heart for mapping experiments and radioligand binding assay. After the experiment, tissue was immediately placed in cardioplegic solution. Left ventricle, septum and right ventricle were excised and subsequently shock-frozen. 
We investigated 4 groups of rabbits: healthy control animals $(n=10)$, doxorubicine-induced heart failure $(n=6)$, doxorubicine-induced heart failure with sham operation $(\mathrm{n}=8)$, and doxorubicine-induced heart failure with stem cell treatment $(n=14)$. During the investigations and subsequent evaluations the experimentators were blinded.

\section{Stem cell purification and subcultivation}

Under sterile conditions we obtained $1.5-2 \mathrm{ml}$ bone marrow in $2 \mathrm{mM}$ EDTA containing phosphate buffered saline (PBS) from a femur punction. The mixture was initially centrifuged at $300 \mathrm{~g}$, at room temperature (RT), for $5 \mathrm{~min}$, and the resulting pellet was resuspended in PBS containing $2 \mathrm{mM}$ EDTA, and separated in a Ficoll (1.073 $\mathrm{g} / \mathrm{ml}$ ) density gradient centrifugation (cell suspension : ficoll: 1.5: 1.0; 30 min centrifugation at $500 \mathrm{~g}$, RT). The mononuclear fraction interphase was collected, washed twice in PBS/EDTA. The final pellet was resuspended in 12 ml Dulbeccos Modefied Eagle Medium (DMEM) cell culture medium (+ $10 \%$ fetal calf serum, $100 \mathrm{U} / \mathrm{ml}$ penicillin, $100 \mu \mathrm{g} / \mathrm{ml}$ streptomycine; $37^{\circ} \mathrm{C}, 5 \% \mathrm{CO}_{2}$ ) and seeded on gelatine-coated petridishes. For the first 24 hours cells were incubated with additional $10 \mu \mathrm{M}$ 5-azacytidine. Cells were cultured for 4 days. Cell culture medium was changed every $48 \mathrm{~h}$, and non-adherent hematopoetic cells were discarded. Prior to transplantation cells were detached with trypsin/EDTA, and incubated with $2.5 \mu \mathrm{M}$ Vybrand DiI cell labelling solution (Molecular Probes) for $0.5 \mathrm{~h}$ protected from light in the incubator at $37^{\circ} \mathrm{C}$ followed by 3 washing steps in PBS. Finally, the resulting mesenchymal mononuclear c-kit positive bone marrow stem cells (tested using a commercial anti-c-kit antibody) were suspended in DMEM for injection (1.5-2.0 Mio. cells in $1 \mathrm{ml}$ ).

\section{Radioligand binding study}

$\beta$-adrenoceptors were assessed by (-) [125I]-iodocyanopindolol (ICYP)-binding assay described elsewhere [29]. Briefly, tissue samples from right ventricle, left ventricle and septum were homogenised in 10 volumes of ice-cold $1 \mathrm{mmol} / \mathrm{K} \mathrm{KHCO}_{3}$ with an Ultra Turrax (Janke and Kunkel, Staufen, Germany), diluted to $20 \mathrm{ml}$ with $1 \mathrm{mmol} / \mathrm{l}$ $\mathrm{KHCO}_{3}$, centrifuged at $500 \mathrm{~g}$ for $10 \mathrm{~min}$, passed through 4 layers of cheesecloth, and centrifuged again at 50,000 g for $20 \mathrm{~min}$. Pellets were washed once by resuspension and recentrifugation and finally resuspended in incubation buffer (Tris-HCl 10, NaCl 154, ascorbic acid $0.55 \mathrm{mmol} /$ $1, \mathrm{pH} 7.4,25^{\circ} \mathrm{C}$ ) at a protein concentration of $0.1-0.2 \mathrm{mg} /$ $\mathrm{ml}$. Protein content was determined by the method of Lowry using bovine serum albumine as a standard.

The density of $\beta$-adrenoceptors in cardiac membranes was determined by (-) [125I]ICYP binding at six concentrations ranging from 5 to $200 \mathrm{pmol} / \mathrm{l}$ as detailed elsewhere [29]. Non-specific binding of ICYP was defined as binding to membranes which could not be displaced by a high concentration of the non-selective $\beta$-adrenoceptor antagonist ( \pm ) CGP $12177(1 \mu \mathrm{mol} / \mathrm{l})$. Specific binding was defined as total binding minus non-specific binding and usually was about $70-80 \%$ at $50 \mathrm{pmol} / \mathrm{l}$ ICYP.

To determine the relative amounts of $\beta_{1}$ - and $\beta_{2}$-adrenoceptors, membranes were incubated with increasing concentrations of the $\beta 2$-adrenoceptor antagonist ICI $118,551\left(10^{-10}-10^{-4} \mathrm{M}\right)$ and a constant concentration of ICYP (100 pmol/l), and the specific binding assessed as described above (using CGP12177). Binding curves were analysed using the iterative curve fitting program GraphPadPrism (GraphPad Software, San Diego, CA, USA).

\section{High Pressure Lquid Chromatography (HPLC)}

Plasma norepinephrine content was assessed by highpressure liquid chromatography (HPLC) and electrochemical detection [30] using a commercial HPLC assay (Chromsystems, Martinsried, Germany) based on the protocol by Goldstein [31] and by Hjemdahl et al. [32]. Briefly, catecholamines were adsorbed to aluminiumoxide (in prepacked columns; Chromsystems, Martinsried, Germany) by shaking $1 \mathrm{ml}$ plasma with $0.5 \mathrm{ml}$ extraction buffer (Tris-buffer) and aluminiumoxide for $10 \mathrm{~min}$. As internal standard $600 \mathrm{pg}$ dihydroxybenzylamine were added to the plasma sample. After $10 \mathrm{~min}$, the probe was washed twice and washing buffer was removed. Thereafter, the bound catecholamines and internal standard were eluted using $120 \mu \mathrm{l}$ elution buffer (Chromsystems, Martinsried, Germany) and filtration (at $700 \mathrm{~g}$ ). $40 \mu$ l probe volume were injected at a flow of $1 \mathrm{ml} / \mathrm{min}$ (HPLC autosampler (GINA50) and pump (P580): Gynkotec, Germering, Germany; mobile phase 5001; Chromsystems, Martinsried, Germany) on a pre-equilibrated RP18 column (Chromsystems, Martinsried, Germany). The HPLC system was controlled by the Chromeleon software 4.10 (Gynkotec, Germering, Germany). Catecholamines were detected using an electrochemical detector (DECADE; flow cell: VT-03; Fa. ANTEC Comp., Leyden, Netherlands) (a working potential of $0.55 \mathrm{~V}$ yielded maximum signals with lowest noise). An external calibration standard containing $5 \mathrm{ng} / \mathrm{ml}$ norepinephrine, $5 \mathrm{ng} / \mathrm{ml}$ dihydroxybenzylamine, $2.5 \mathrm{ng} / \mathrm{ml}$ epinephrine and $2.5 \mathrm{ng} / \mathrm{ml}$ dopamine was also used for each experiment. Each sample was injected three times and the concentration was determined as the mean of these three detections.

\section{Histology}

Tissue samples of the hearts were embedded in paraffin and $5 \mu \mathrm{m}$ sections of the hearts were stained with picrosirius red according to standard protocols. Using fluorescence microscopy we identified the BMSC or their remnants by Vybrand-DiI-red fluorescence and counted the number of these BMSC (or remains) per visual field at 
Left ventricle

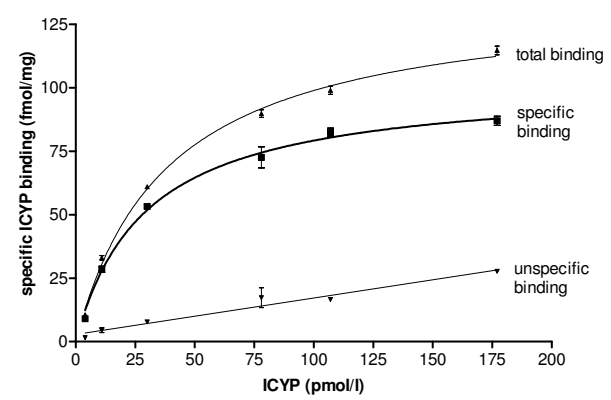

Right ventricle

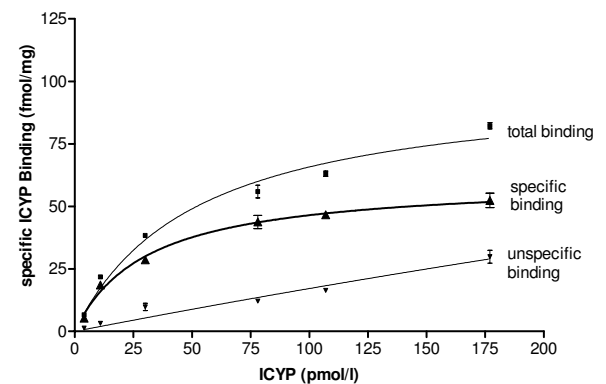

Septum

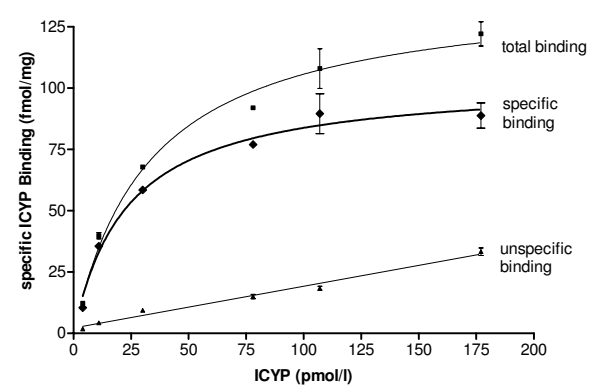

Figure I

representative original ICYP binding data for one animal (k042) from the control group given for left ventricle, septum and right ventricle as total binding, unspecific binding and specific binding.

$200 \times$ magnification. Moreover, we looked for signs of inflammation, i.e. leukocyte/lymphocyte infiltration.

\section{Mapping experiments}

In order to investigate, whether BMSC injection might produce inhomogeneities in the cardiac electrical activation pattern or autonomic areas, we submitted 4 hearts of each group to epicardial mapping as previously described [33]. Briefly, rabbits were anaesthetized by isoflurane, the heart was excised and prepared according to the Langendorff technique (constant pressure: $70 \mathrm{~cm} \mathrm{H2O}$, perfusion with Tyrode solution $\left(\mathrm{Na}^{+} 161.02, \mathrm{~K}^{+} 5.36, \mathrm{Ca}^{++} 1.8, \mathrm{Mg}^{++}\right.$ 1.05, $\mathrm{Cl}^{-}$147.86, HCO3- 23.8, $\mathrm{PO}^{2-} 0.42$ and glucose $11.1 \mathrm{mM}$, equilibrated with 95\% O2 and 5\% CO2 (pH = 7.4); the surface temperature of the heart was $37^{\circ} \mathrm{C}$ ). The hearts, which were beating at their spontaneous rate, were connected to a 256 channel mapping system HAL4 (Ing.
Buero Peter Rutten, Hamburg, Germany, temporal resolution: $20 \mathrm{kHz}$ per channel; amplitude resolution: $0.04 \mathrm{mV}$, interchannel coupling <-60 decibel; bandwidth of the system: $0.5 \mathrm{~Hz}$ - $100 \mathrm{kHz}$, data were not filtered) as described previously [33]. $256 \mathrm{AgCl}$ electrodes (1 mm interelectrodes distance), which were attached to the heart surface in an elastic manner, so that they could follow the heart movements easily without dislocation. The four plates were located at (a) the right wall (64 channels) (b) the front wall ( 64 channels) (c) the left wall (64 channels) and (d) the back wall ( 64 channels), so that both ventricles were mapped with a total of 256 electrodes. Activation and repolarization time points at each electrode were determined as $\mathrm{t}(\mathrm{dU} / \mathrm{dtmin})$ or $\mathrm{t}\left(\mathrm{dU} / \mathrm{dt}_{\max }\right)$, respectively [33-35]. After automatic determination activation and repolarization timepoints were verified (or corrected if necessary) manually by the experimentator. Total activation time (TAT, [ms]) was calculated as the delay between activation of the first and activation of the last electrode. Standard deviation of activation times (SD(ACT)) was used as a measure for local inhomogeneity. For each electrode an activation-recovery-interval (ARI, reflecting epicardial potential duration) was calculated. Inhomogeneity of ARI was analyzed calculating standard deviation of ARI at 256 electrodes (=ARI-dispersion).

\section{Statistics}

All continuous variables are presented as means \pm S.E.M. of $\mathrm{n}$ experiments. Experimental data to $\beta$-adrenoceptors were fitted and analysed by computer-supported iterative non-linear regression analysis using the GraphPadPrism program (GraphPAD Software; San Diego, CA, USA). Statistical significance of differences was analysed by unpaired two-tailed Student's t-test or, if appropriate, by repeated measures ANOVA followed by t-test using Bonferroni corrections for multiple comparisons. $\mathrm{P}<0.05$ was considered to indicate a significant difference. The statistical evaluation was performed using SYSTAT program (Systat Inc., Evanston, IL, USA).

\section{Chemicals}

CGP12177, ICI118,551 were from Sigma (Taufkirchen, Germany), (-) [125I]iodocyanopindolol (ICYP, specific activity: $2200 \mathrm{Ci} / \mathrm{mmol}$ ) (Perkin Elmer, Boston, MA, USA), all other chemicals were of the purest commercially available grade and obtained from Sigma.

\section{Results}

We found saturable ICYP binding in the membrane preparations of all hearts. Unspecific binding was below 20\% of total binding at $\mathrm{K}_{\mathrm{D}}$ (example is given in fig. 1, upper panel). Specific binding revealed different $\beta$-adrenoceptor densities in left ventricle, septum and right ventricle with lowest values in the right ventricle (fig. 1). Displacement of ICYP by ICI 118,551 revealed a monophasic competi- 


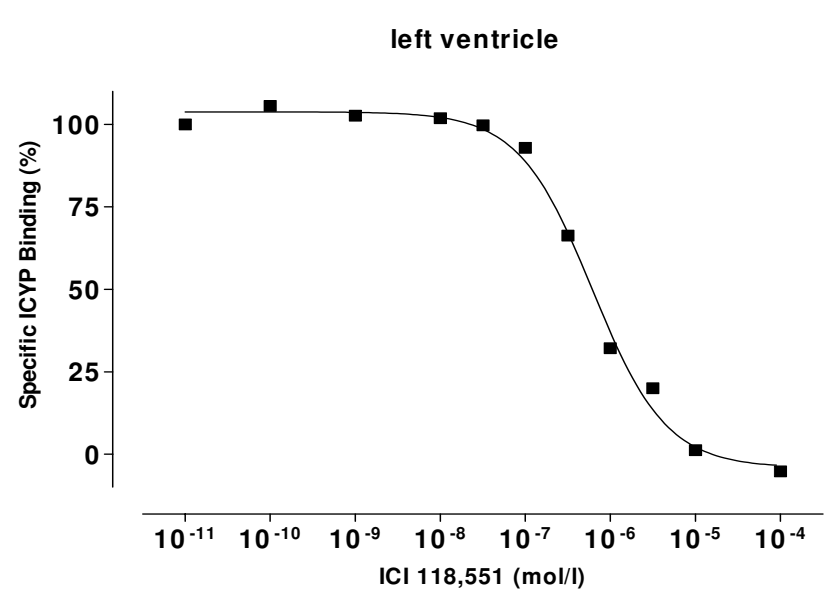

Figure 2

Displacement of ICYP binding by increasing concentrations of the $\beta_{2}$-adrenoceptor ligand ICI II8,55I, revealing a monophasic competition, which means that there is almost no $\beta_{2}$-adrenoceptor fraction.

tion curve and a nearly undetectable $\beta_{2}$-adrenoceptor population (fig. 2).

Regarding the effects of disease and treatment, we found significant down-regulation of $\beta$-adrenoceptor density in untreated heart failure as compared to control (fig. 3). This down-regulation was attenuated in BMSC-treated animals (fig. 3). In sham operated animals with vehicle injection, however, we found nearly the same down-regulation as in failing hearts (fig. 4). The $\beta$-adrenoceptor down-regulation in failing hearts was accentuated in septum and left ventricle (fig. 4). Most interestingly, in failing hearts receiving BMSC transplantation the $\beta$-adrenoceptor

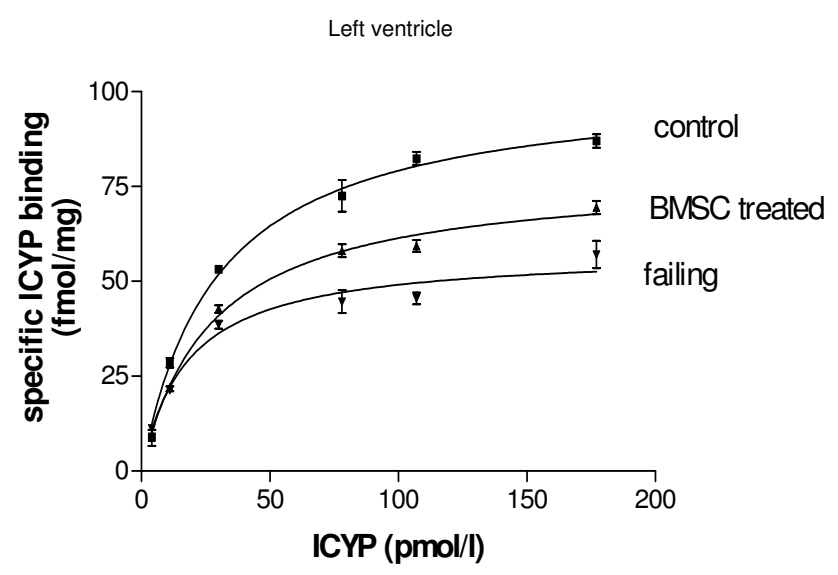

Figure 3

Binding curves for control hearts, failing hearts and BMSCtreated failing hearts showing specific ICYP binding for left ventricle. down-regulation was significantly attenuated in septum and left ventricle as compared to sham operated failing hearts (fig. 4). $\beta$-adrenoceptor density was nearly normalized in septum of BMSC treated hearts and significantly enhanced in left ventricle (as compared to sham operated hearts), although still below the normal level (fig. 4). $\mathrm{K}_{\mathrm{D}}$ was similar among all groups indicating unchanged affinity (given in the legend to fig. 4).

Regarding catecholamine plasma concentrations HPLC revealed clear and sharp peaks for norepinephrine, epinephrine and internal standard (fig. 5, panel A). In rabbits with untreated heart failure we found significantly enhanced norepinephrine and epinephrine levels (fig. 5, panel $\mathrm{B}$ ). The same holds true for rabbits suffering from heart failure receiving sham-operation. In contrast, in rabbits with heart failure treated with BMSC transplantation norepinephrine and epinephrine plasma levels were significantly lower than in untreated or sham-operated rabbits (fig. 5, panel B).

In line with these findings, invasive in-vivo contractility testing with Millar catheter revealed significantly improved contractility in the BMSC treated animals (see table 1). Thus, $\mathrm{dP} / \mathrm{dtmax}$ and $\mathrm{dP} / \mathrm{dtmin}$ under stimulation with $1.5 \mu \mathrm{g} / \mathrm{kg}$ dopamine were largely decreased in failing hearts and sham-operated failing hearts, while in failing hearts which received BMSC transplantation this parameter was significantly enhanced (see table 1 ). Pearson correlation of $\beta$-adrenoceptor density and contractility ( $\mathrm{dP} /$ $\mathrm{dt}_{\max }$ ) revealed a significant correlation with $\mathrm{R}^{2}=0.887$ and $\mathrm{p}<0.05$.

By histological investigation of the hearts we found 2-3 intact cells/visual field (magnification $200 \mathrm{x}$ ) and some remnants showing Vybrand DiI red fluorescence in BMSC treated hearts in the vicinity of the injection marks, but not in sham-operated or control hearts. However, these few cells were found only in close neighbourhood of the injection. In that area we also detected red fluorescent cell detritus (fig. 6). We did not observe marked signs of an inflammatory response such as leukocyte or lymphocyte infiltration. However, in most normal, failing and treated hearts a mild interstitial fibrosis was observed (fig. 6), which was slightly more expressed in all failing hearts. At the site of injection, we found a fibrotic scar (fig. 6). In all animals suffering from heart failure body weight was reduced and heart weight/body weight ratio was increased. There were no significant differences among the heart failure groups (table 1).

Regarding the subgroup of hearts which underwent mapping experiments, we found regularly beating hearts with undisturbed propagation of the cardiac activation wave front (fig. 7). The total activation time (TAT) was not dif- 
$B(\max )$

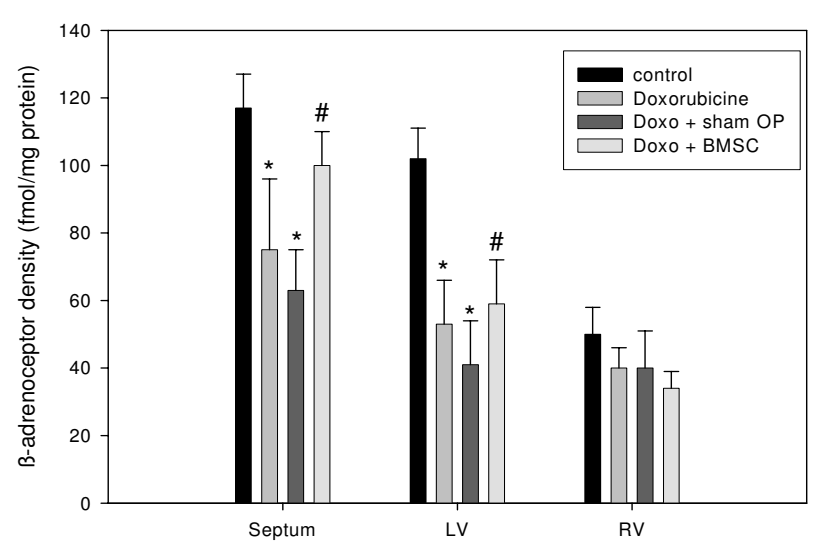

Figure 4

Quantitative data for $\beta$-adrenoceptor density in normal hearts, failing hearts, sham-operated failing hearts and BMSC transplanted failing hearts, given for left ventricle, septum and right ventricle as MEANS \pm SEM of $n=6$ hearts in each group. Significant differences versus normal hearts are indicated by a $*(p<0.05)$, while significant changes versus shamoperated hearts are indicated by a \# $(p<0.05)$. Corresponding data for KD (septum, left ventricle (LV), right ventricle (RV)) were: $37 \pm 3,35 \pm 4,42 \pm 3$ (controls), $48 \pm 6,44 \pm 6$, $48 \pm 7$ (doxorubicine), $47 \pm 5,46 \pm 6,48 \pm 9$ (sham operated hearts), $42 \pm 9,53 \pm 8,57 \pm 14$ (BMSC transplanted hearts); there were no significant differences between the KD values.

ferent among the groups as was the standard deviation of the activation times at the 256 electrodes, which reflects the inhomogeneity of the activation process (table 2; fig. 7 ). Thus, inhomogeneity of the activation process was not enhanced by BMSC transplantation. The activation-recovery intervals (ARI) were not changed by BMSC injection versus sham-operated animals and the dispersion of ARI also was not changed (table 2). We never observed spontaneously depolarizing areas in the ventricles or sustained arrhythmia. The only finding was that in all failing heart groups ARI was somewhat prolonged but without reaching the level of significance.

\section{Discussion}

The results of our study clearly show -to the best of our knowledge for the first time- an improvement and -as assessed by $\beta$-adrenoceptor density- long-term improvement of cardiac hemodynamic function by autologous mesenchymal bone marrow stem cell transplantation in a model of non-ischemic cardiomyopathy. Pathophysiologically the findings can be explained by the assumption that doxorubicine-induced heart failure results in compensatory catecholamine release (see fig. 5, panel B) which in turn leads to $\beta$-adrenoceptor down-regulation (see fig. 4). It is known that changes in $\beta$-adrenoceptor density as a consequence of altered catecholamine levels or $\beta$-blocker therapy in chronic heart failure mostly need days or weeks to develop being related to the severity of the disease $[13,14,25-27,36]$. If according to these studies a therapy of heart failure is hemodynamically effective, one has to assume that catecholamine release should diminish and $\beta$-adrenoceptor density increased towards normal values. This very point could be demonstrated with the data in this paper showing a normalization of both catecholamine levels and $\beta$-adrenoceptor density together with improved contractility after BMSC transplantation. Since it has been shown that normalization of $\beta$-adrenoceptor density needs longer time periods with improved hemodynamics $[25,26]$, we assume that these findings indicate a long-term improvement of cardiac function by BMSC transplantation within the limitations of this model. The positive and significant correlation between $\beta$-adrenoceptor density and contractility $\left(\mathrm{R}^{2}=\right.$ $0.887, \mathrm{p}<0.05)$ supports the hypothesis on a relationship between these two parameters. A point worth discussing is the finding that the effects of BMSC transplantation are more pronounced in the septum than in the free left ventricular wall: the BMSC were injected in the free left ventricular wall at 10 sites. Each injection produced a scar (fig. 6) at the site of injection. In a tiny heart as the rabbit heart 4 injections and the resulting scars will increase the amount of fibrous tissue, which will not occur in the septum, since there are no injections made due to technical reasons of the operation procedure. The scars and the resulting change in the tissue composition in the left free wall may overshadow in parts the effects of BMSC transplantation on $\beta$-adrenoceptor density, which can be better

Table I: Contractility given as $\mathrm{dP} / \mathrm{dt}_{\max }$ and $\mathrm{dP} / \mathrm{dt}_{\min }(\mathrm{mm} \mathrm{Hg} / \mathrm{s})$, body weight $(\mathrm{g})$ and heart weight/body weight ratio $(\mathrm{mg} / \mathrm{g})$, given as MEANS \pm SEM for each group. Significant differences versus normal animals are indicated by $a *(p<0.05)$, while significant changes versus sham-operated rabbits are indicated by a \# $(p<0.05)$.

\begin{tabular}{|c|c|c|c|c|}
\hline Series & $\mathrm{dP} / \mathrm{dt}_{\max }$ & $\mathrm{dP} / \mathrm{dt}_{\min }$ & Body weight & Heart weight/body weight \\
\hline Control & $2603 \pm 281$ & $-2102 \pm 241$ & $3633 \pm 83$ & $3.23 \pm 0.10$ \\
\hline Doxorubicine & $1001 \pm 126^{*}$ & $-759 \pm 86^{*}$ & $2587 \pm 79 *$ & $4.12 \pm 0.27^{*}$ \\
\hline Sham-operated & $1290 \pm 138^{*}$ & $-860 \pm 93 *$ & $2544 \pm 84^{*}$ & $4.40 \pm 0.20 *$ \\
\hline BMSC transplanted & $2084 \pm 151 \#$ & $-1616 \pm 97 \#$ & $2586 \pm 79 *$ & $4.10 \pm 0.20 *$ \\
\hline
\end{tabular}


A

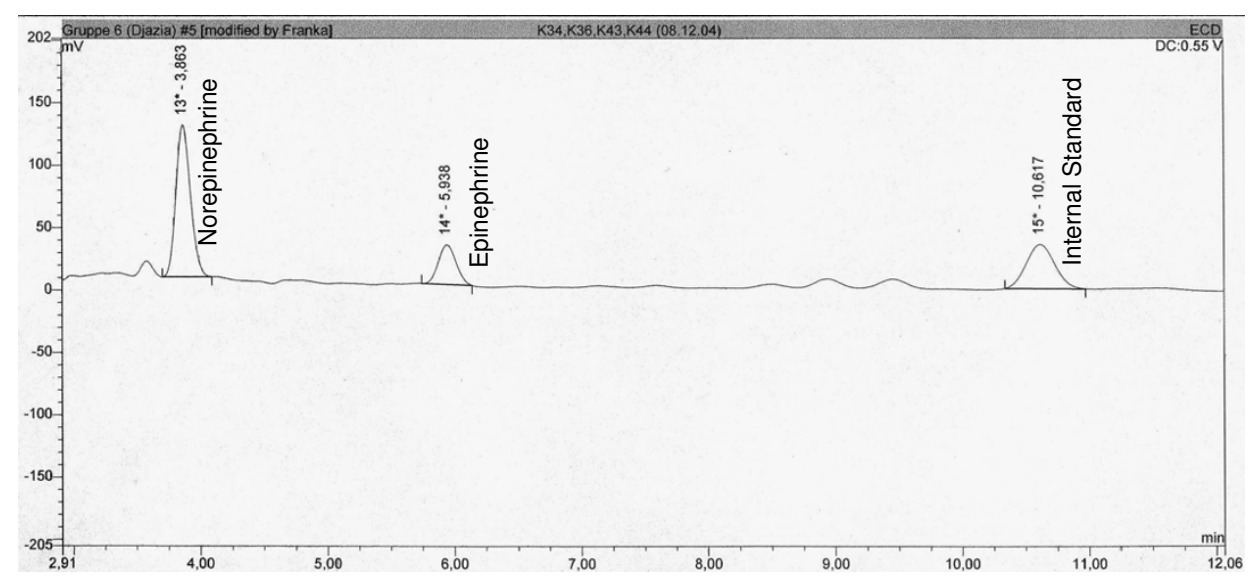

B

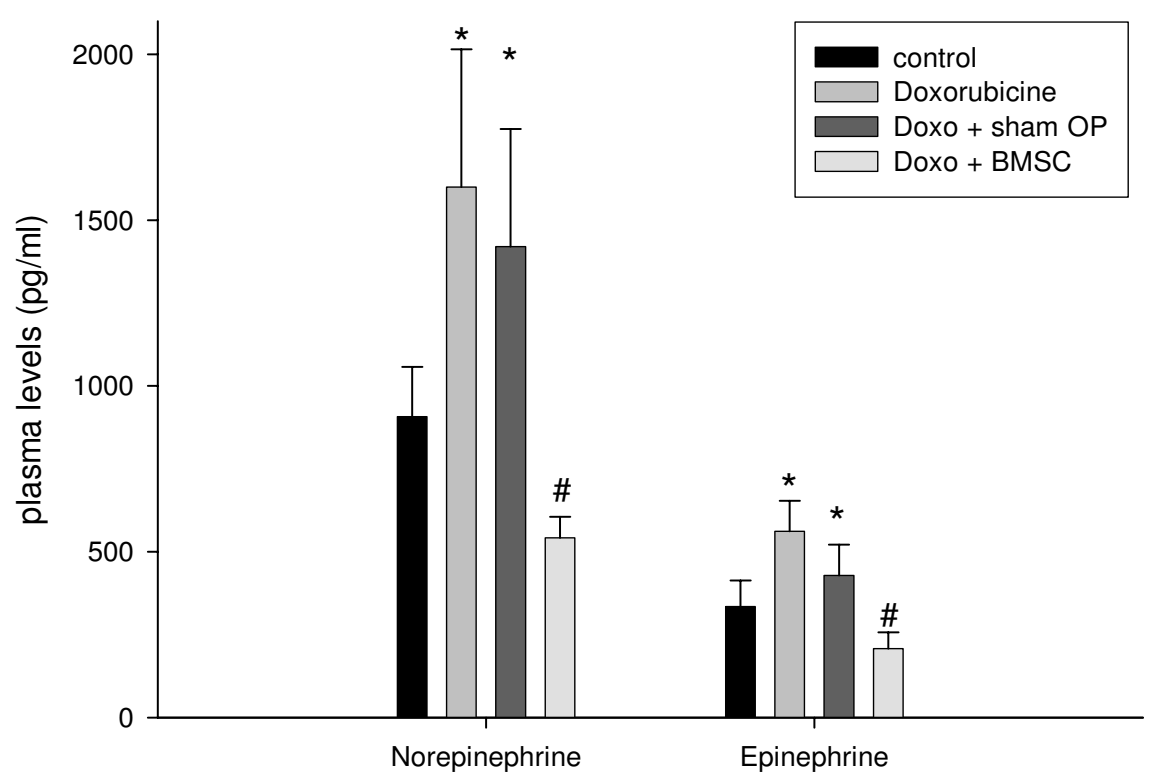

\section{Figure 5}

upper panel (A): original plot showing electrochemical detection of norepinephrine, epinephrine and internal standard in rabbit plasma. lower panel (B): Quantitative data for plasma catecholamines in normal rabbits, in rabbits with doxorubicine-induced heart failure, rabbits suffering from heart failure after sham-operation, and BMSC transplanted rabbits with failing hearts, given as MEANS \pm SEM of $n=6$ rabbits in each group. Significant differences versus normal animals are indicated by a $*(p<0.05)$, while significant changes versus sham-operated rabbits are indicated by a \# $(p<0.05)$. 


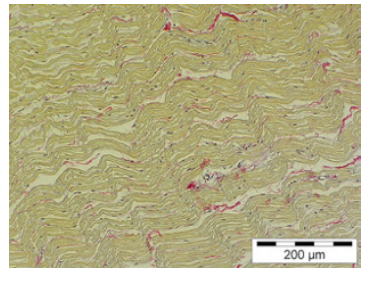

control

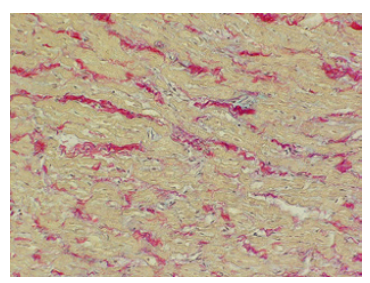

Doxorubicine + sham OP

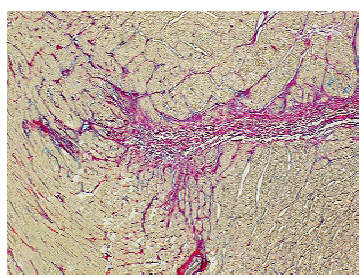

Injection

site

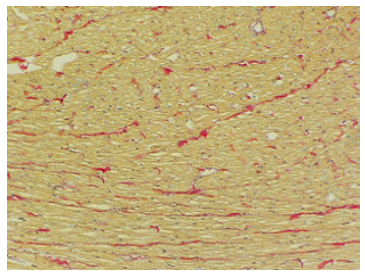

doxorubicine

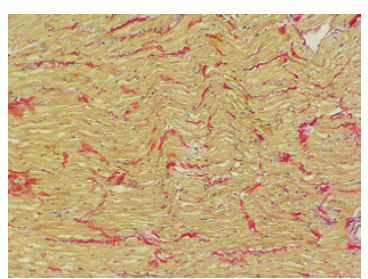

Doxorubicine + BMSC

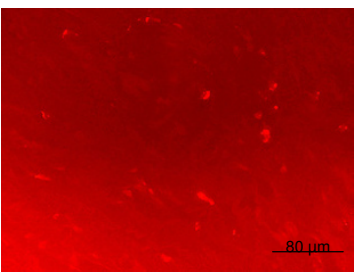

Remnants of the BMSC

\section{Figure 6}

Picrosirius red staining of the hearts of the control, doxorubicine, sham-operated, and BMSC-transplanted group. As can be seen there is a mild interstitial fibrosis in all hearts, which is slightly more pronounced in the failing hearts. At the lower left, an injection site is shown, exhibiting the formation of a scar. At the lower right, red fluorescent cell detritus and some intact fluorescing cells are shown, which were found close to the injection site.

seen in the non-injected septum, if the hemodynamic situation is improved.

Regarding the relation between catecholamine levels and $\beta$-adrenoceptor density and contractility, it is difficult to say what is first. One may speculate, that the improved hemodynamic situation should result in decreased catecholamine levels, and that this will consequently lead to attenuation of $\beta$-adrenoceptor down-regulation. However, it is also possible that BMSC-transplantation primarily leads to enhanced $\beta$-adrenoceptor density or attenuated down-regulation possibly by a paracrine effect, which should then -analogous to beta-blocker treatmentlead to an improved hemodynamic situation.

Numerous studies showed positive effects of BMSC transplantation in ischemic heart disease or acute myocardial infarction (e.g. $[4,8,11])$ either by direct infiltration or by intracoronary stem cell injection (for a recent review see [1]). It has been assumed that ischemia leads to expression of yet unknown homing factors attracting the stem cells [37]. In non-ischemic cardiomyopathy it is unclear whether such homing factors exist and, thus, we decided to use direct myocardial infiltration technique for BMSC application. The finding that we only found BMSC or their remains in close vicinity of the injection speaks somewhat against a predominant role of homing factors in this model of non-ischemic cardiomyopathy although for a final statement on this point (which was not the focus of our study) experiments using e.g. intracoronary application will be needed. Nevertheless, our data present the first evidence for the efficacy of BMSC transplantation in non-ischemic cardiomyopathy.

Regarding the underlying mechanisms of BMSC transplantation there is an ongoing debate discussing factors such as angiogenetic effects, transdifferentiation, cell fusion and the release of paracrine factors [1,38]. First of all, the lack of effect of medium injection (see sham-operated animals) demonstrates that it is not the trauma of operation and injection; moreover, one could hypothesize that the BMSC injection might induce an inflammatory response (although the cells are autologous). However, we have no indication of a inflammatory lymphocyte or leukocyte infiltration of the ventricular myocardium, which clearly is against the hypothesis of an unspecific inflammation. Moreover, the sham operated hearts were also injected with medium, but did neither show inflammatory response nor therapeutic effect. A

Table 2: Electrophysiological findings of healthy, doxorubicine-treated and BMSC-treated rabbits in comparison to sham-operated animals. (Abbreviations: TAT: total activation time; ARI = activation-recovery interval; SD(ACT) : standard deviation of activation time; DISP: dispersion defined as standard deviation of activation-recovery interval). The differences among the groups were not significant.

\begin{tabular}{lllll}
\hline Series & TAT & SD $($ ACT $)$ & ARI & DISP \\
\hline Control & $17.3 \pm 2.7$ & $0.24 \pm 0.04$ & $128.4 \pm 16.3$ & $18.4 \pm 2.4$ \\
Doxorubicine & $18.1 \pm 3.1$ & $0.26 \pm 0.04$ & $147.1 \pm 6.6$ & $13.3 \pm 1.0$ \\
Sham-operated & $18.7 \pm 4.3$ & $0.28 \pm 0.05$ & $143 \pm 7.4$ & $14.1 \pm 0.8$ \\
BMSC transplanted & $19.5 \pm 1.8$ & $0.28 \pm 0.03$ & $141.6 \pm 10.3$ & $18.8 \pm 3.5$ \\
\hline
\end{tabular}




\section{heart failure}

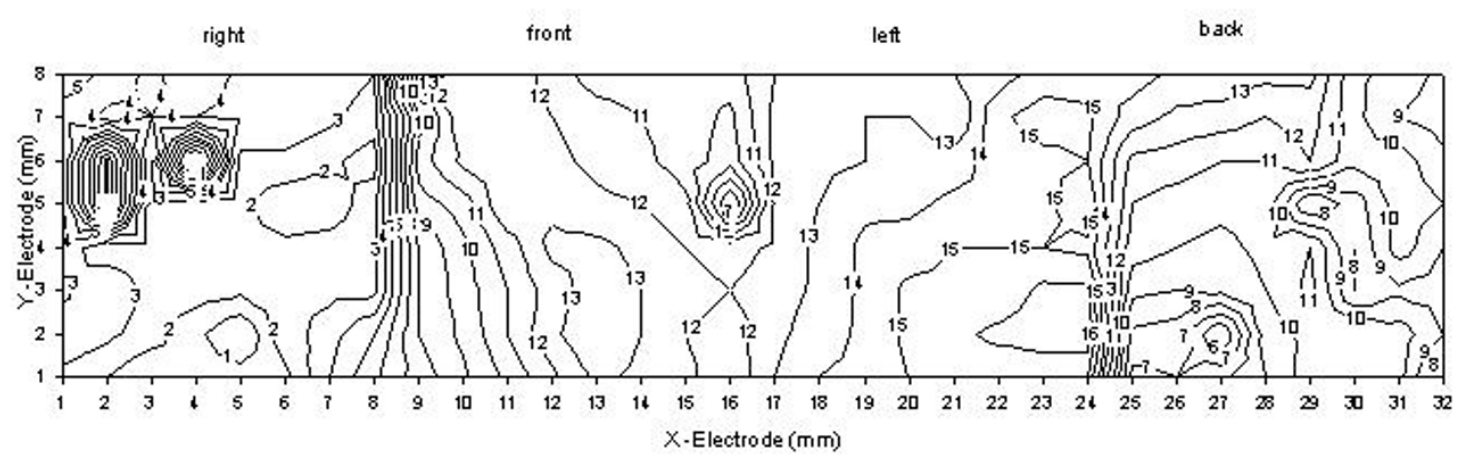

BMSC

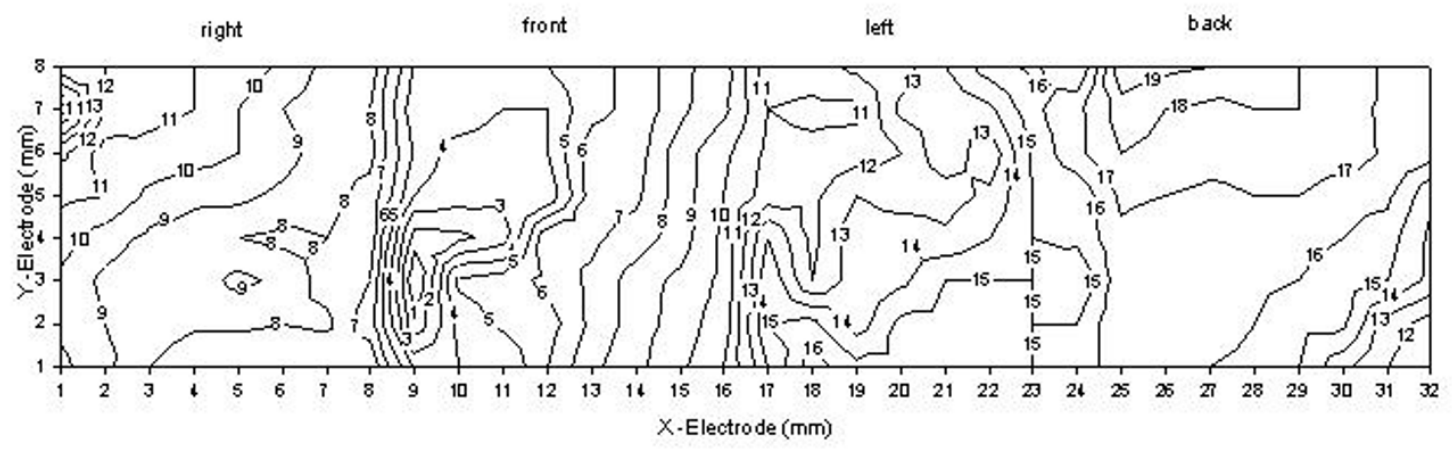

\section{Figure 7}

Original isochrones (spacing I ms) of the epicardial activation of the hearts surface in an untreated failing heart (upper) and a BMSC-treated (lower) failing heart (Y-electrode row I is caudal, while Y-electrode 8 is cranial; $X$-electrode location is indicated in the plot as right, front, left or back wall of the ventricles). Cumulative data for all hearts of this series are given in table 2.

myocardial transdifferentiation of BMSC, a hypothesis broad forward by e.g. Tomita et al. [4] and others [5,39], cannot be completely ruled out, but with $2-3$ cells/visual field at $200 \mathrm{x}$ magnification and only in vicinity of the injection) we have no indication for an amount of cells undergoing transdifferentiation (or even being present as they are) which would be large enough to explain the contractile and hemodynamic improvement. Instead, one could imagine that the injected cells release paracrine factors, yet unknown (or see above), which cause a response of the surrounding myocardial tissue (including all types of cells) being responsible for the process. Future studies will have to be directed to the investigation of this hypothesis and the identification of possible paracrine effects, if existing.

Regarding the safety of BMSC transplantation the results obtained with skeletal myoblasts indicate a possible arrhythmogenic risk of cell therapy [40-42], so that a deeper investigation seems to be necessary. Therefore, we decided to investigate a subset of hearts by means of epicardial potential mapping. We checked the number of epicardial breakthroughpoints, looked for arrhythmogenic foci and signs of inhomogeneity such as delayed activation or increased dispersion. None of these parameters was different in BMSC transplanted hearts from failing hearts without therapy. This does not completely rule out arrhythmogeneic effects of this therapy in other (in particular later) phases of the therapy but these results show that at least after 4 weeks no autonomic areas or nonexcitable zones (larger than $0.5 \mathrm{~mm}^{2}$ ) have been induced by the therapy. Taking the low number of surviving cells into account this seems reasonable. Thus, with all caution, we have at present no indication of an arrhythmogenic effect of autologous BMSC transplantation in nonischemic cardiomyopathy within the limitations of this model. 


\section{Conclusion}

The mechanism by which stem cell transplantation leads to improvement of cardiac function is still uncertain and further studies are on the way to elucidate this question. The small number of surviving BMSC in our study is in favour of the assumption of indirect effects such as e.g. paracrine effects. Our data clearly show a long-term improvement in cardiac function by autologous stem cell therapy in non-ischemic cardiomyopathy, so that we conclude that this might be an interesting new therapeutic approach to the treatment of non-ischemic cardiomyopathy.

\section{Competing interests}

The author(s) declare that they have no competing interests.

\section{Authors' contributions}

Stefan Dhein had the idea of the study, performed data analysis, statistics, graphics, and wrote the paper. Jens Garbade did the surgery on the animals, isolated and characterised the stem cells, and performed investigations of contractility; Jan Fritz Gummert and Friedrich-Wilhelm Mohr, both helped with the surgical techniques and added important comments to the paper; Djazia Rouabah, Getu Abraham, and Fritz-Rupert Ungemach performed the radioligand binding studies and analysed the binding curves.

Katja Schneider performed anaesthesia of the animals and the postoperative animal care. Cris Ullmann developed the software for the pressure volume loops analysis and analysed these data, Heike Aupperle performed all histological work on the hearts, and analysed the cell number of surviving stem cells.

\section{Acknowledgements}

This study was generously supported by a grant from the Deutsche Stiftung für Herzforschung given to Stefan Dhein.

\section{References}

I. Dimmeler S, Zeiher AM, Schneider MD: Unchain my heart: the scientific foundations of cardiac repair. I Clin lnvest 2005, I I 5:572-583.

2. Zimmet JM, Hare JM: Emerging role for bone marrow derived mesenchymal stem cells in myocardial regenerative therapy. Basic Res Cardiol 2005, 100:47I-48I.

3. Ott HC, McCue J, Taylor DA: Cell-based cardiovascular repair the hurdles and the opportunities. Basic Res Cardiol 2005, 100:504-5I7.

4. Tomita S, Li RK, Weisel RD, Mickle DA, Kim EF, Sakai T, Jia FQ: Autologous tranplantation of bone marrow cells improves damaged heart function. Circulation 1999, 100:247-256.

5. Orlic D, Kajstura J, Chimenti S, Jakoniuk I, Anderson SM, Li B, Pickel J, Mc Kay R, Nadal-Ginard B, Bodine DM, Leri N, Anversa P: Bone marrow cells regenerate infarcted myocardium. Nature 200I, 41 0:702-705.

6. Kawamoto A, Gwon HC, Iwaguro H, Yamaguchi II, Uchida S, Masuda $\mathrm{H}$, Silver M, Ma H, Kearney M, Isner JM, Asahara T: Therapeutic potential of ex vivo expanded endothelial progenitor cells for myocardial ischemia. Circulation 200I, 103:634-637.
7. Strauer BE, Brehm M, Zeus T, Gattermann N, Hernandenz A, Sorg RV, Kogler G, Wernert P: Myocardial regeneration after intracoronary transplanatation of human autogous stem cells following acute myocardial infarction. Dtsch Med Wochenschr 200I, I 26:932-938.

8. Strauer BE, Brehm M, Zeus T, Köstering M, Hernandez A, Sorg RV, Kögler $G$, Wernet $P$ : Repair of infarcted myocardium by autologous intracoronary mononuclear bone marrow cell transplantation in humans. Circulation 2002, 106:1913-1918.

9. Wollert KC, Meyer GP, Lotz J, Ringes-Lichtenberg S, Lippolt P, Breidenbach C, Fichtner S, Korte T, Hornig B, Messinger D, Arseniev L, Hertenstein B, Ganser A, Drexler H: Intracoronary autologous bone-marrow cell transfer after myocardial infarction: the BOOST randomised controlled clinical trial. Lancet 2004, 364(9429): $|4|-8$.

10. Perin EC, Dohmann HF, Borojevic R, Silva SA, Sousa AL, Silva GV, Mesquita CT, Belem L, Vaughn WK, Rangel FO, Assad JA, Carvalho AC, Branco RV, Rossi MI, Dohmann HJ, Willerson JT: Improved exercise capacity and ischemia 6 and 12 months after transendocardial injection of autologous bone marrow mononuclear cells for ischemic cardiomyopathy. Circulation 2004, I I O(I I SuppI I):II2 I3-8.

II. Schachinger V, Assmus B, Britten MB, Honold J, Lehmann R, Teupe C, Abolmaali ND, Vogl TJ, Hofmann WK, Martin H, Dimmeler S, Zeiher AM: Transplantation of progenitor cells and regeneration enhancement in acute myocardial infarction: final one-year results of the TOPCARE-AMI Trial. J Am Coll Cardiol 2004, 44:1690-1699.

12. Böhm M, Diet F, Feiler G, Kemkes B, Kreuzer E, Weinhold C, Erdmann $E$ : Subsensitivity of the failing human heart to isoprenaline and milrinone is related to beta-adrenoceptor downregulation. J Cardiovasc Pharmacol 1988, 1 2:726-732.

13. Bristow MR, Ginsburg R, Minobe W, Cubicciotti RS, Sageman WS, Lurie K, Billingham ME, Harrison DC, Stinson EB: Decreased catecholamine sensitivity and beta-adrenergic-receptor density in failing human hearts. N Engl J Med I 982, 307:205-2II.

14. Brodde OE, Michel MC, Zerkowski H-R: Signal transduction mechanisms controlling cardiac contractility and their alterations in chronic heart failure. Cardiovasc Res 1995, 30:570-584.

15. Kiuchi K, Shannon RP, Komamura K, Cohen DJ, Bianchi C, Homcy CJ, Vatner SF, Vatner DE: Myocardial beta-adrenergic receptor function during the development of pacing-induced heart failure. J Clin Invest 1993, $91: 907-914$.

16. Engelhardt S, Böhm M, Erdmann E, Lohse MJ: Analysis of betaadrenergic receptor mRNA levels in human ventricular biopsy specimens by quantitative polymerase chain reactions: progressive reduction of beta I-adrenergic receptor mRNA in heart failure. J Am Coll Cardiol 1996, 27:146- 154.

17. Lohse MJ, Engelhardt $S$, Eschenhagen T: What is the role of $\beta$ adrenergic signalling in heart failure? Circ Res 2003, 93:896-906.

18. Lohse MJ: G-protein coupled receptor kinases and the heart. Trends Cardiovasc Med 1995, 5:63-68.

19. Ungerer M, Böhm M, Elce JS, Erdmann E, Lohse MJ: Altered expression of beta-adrenergic receptor kinase and beta I-adrenergic receptors in the failing human heart. Circulation 1993, 87:454-463.

20. Ungerer M, Parruti G, Böhm M, Puzicha M, DeBlasi A, Erdmann E, Lohse MJ: Expression of beta-arrestins and beta-adrenergic receptor kinases in the failing human heart. Circ Res 1994, 74:206-2I3.

21. Ping P, Anzai T, Gao M, Hammond HK: Adenylyl cyclase and G protein receptor kinase expression during development of heart failure. Am J Physiol 1997, 273:H707-H717.

22. Rockman HA, Koch WJ, Lefkowitz RJ: Seven-transmembranespanning receptors and heart function. Nature 2002, 415:206-2I2.

23. Böhm M, Reiger B, Schwinger RHG, Erdmann E: cAMP concentrations, CAMP dependent protein kinase activity, and phospholamban in non-failing and failing myocardium. Cardiovasc Res 1994, 28:1713-1719.

24. Gilson N, Bouanani NEH, Corsin A, Crotazier B: Left ventricular function and $\beta$-adrenoceptors in rabbit failing hearts. $\mathrm{Am} J$ Physiol 1990, 258: H634-H64l.

25. Gilbert EM, Abraham WT, Olsen S, Hattler B, White M, Mealy P, Larrabee $P$, Bristow MR: Comparative hemodynamic, left ventricular functional, and antiadrenergic effects of chronic 
treatment with metoprolol versus carvedilol in the failing heart. Circulation 1996, 94:2817-2825

26. Sigmund M, Jakob H, Becker H, Hanrath $P$, Schumacher $C$, Eschenhagen T, Schmitz W, Scholz H, Steinfath M: Effects of metoprolol on myocardial beta-adrenoceptors and $\mathbf{G i}$ alpha-proteins in patients with congestive heart failure. Eur J Clin Pharmacol 1996, 5 I:I27-I32.

27. Harding SE, Brown LA, Wynne DG, Davies CH, Poole-Wilson PA: Mechanisms of beta adrenoceptor desensitisation in the failing human heart. Cardiovasc Res 1994, 28: |45 I-I460.

28. Schneider K: Anaesthesia of laboratory animals. In Practical Methods in cardiovascular Research Edited by: Dhein S, Mohr FW, Delmar M. Heidelberg: Springer Verlag; 2005:5-25.

29. Brodde O-E, Vogelsang M, Broede A, Michel-Reher M, BeisenbuschSchäfer E, Hakim K, Zerkowski H-R: Diminished responsiveness of $\mathbf{G}_{\mathrm{s}}$-coupled receptors in severely failing human hearts: no difference in dilated versus ischemic cardiomyopathy. J Cardiovasc Pharmacol 1998, 3 I:585-594.

30. Bauersfeld W, Ratge D, Knoll E, Wisser H: Determination of catecholamines in plasma by HPLC and amperometric detection. Comparison with a radioenzymatic method. J Clin Chem Clin Biochem 1986, 24: 185-188.

31. Goldstein DS: Plasma catecholamines in clinical studies of cardiovascular diseases. Acta Physiol Scand I 984, 527(Suppl):39-4I.

32. Hjemdahl P, Freyschuss U, Juhlin-Dahnfeld A, Linde B: Differentiated sympathetic activation during mental stress evoked by the stroop test. Acta Physiol Scand 1984, 527(Suppl):25-29.

33. Dhein S, Müller A, Gerwin R, Klaus W: Comparative study on the proarrhythmic effects of some antiarrhythmic agents. Circulation 1993, 87:617-630.

34. Durrer D, Van der Tweel LH: Spread of activation in the left ventricular wall of the dog. Activation conditions at the epicardial surface. Am Heart J 1954, 47: 192-203.

35. Millar CK, Kralios FA, Lux RL: Correlation between refractory periods and activation recovery intervals from electrograms: effects of rate and adrenergic interventions. Circulation 1985, 72:1372-1379.

36. Brodde OE, Michel MC: Adrenergic and muscarinic receptors in the human heart. Pharmacol Rev 1999, 51:65I-690.

37. Vandervelde S, van Luyn MJ, Tio RA, Harmsen MC: Signalling factors in stem cell-mediated repair of infracted myocardium. J Mol Cell Cardiol 2005, 39:363-376.

38. Dawn B, Bolli R: Adult bone marrow-derived cells: regenerative potential, plasticity, and tissue commitment. Basic Res Cardiol 2005, 100:494-503.

39. Jackson KA, Majka SM, Wang H, Pocius J, Hartley CJ, Majesky MW, Entman ML, Michael LH, Hirschi KK, Goodell MA: Regeneration of ischemic cardiac muscle and vascular endothelium by adult stem cells. J Clin Invest 2001, 107:1395- I 402.

40. Menasché P, Hagege AA, Scorsin N, Pouzet B, Desnos N, Duboc D, Schwartz KI, Vilquin JT, Marolleau JP: Myoblast transplantation for heart failure. Lancet 200I, 357:279-280.

41. Menasche P, Hagege AA, Vilquin JT, Desnos M, Abergel E, Pouzet B, Bel A, Sarateanu S, Scorsin M, Schwartz K, Bruneval P, Benbunan M, Marolleau JP, Duboc D: Autologous skeletal myoblast transplantation for severe postinfarction left ventricular dysfunction. J Am Coll Cardiol 2003, 4I: I 078-1083.

42. Leobon B, Garcin I, Menasche P, Vilquin JT, Audinat E, Charpak S: Myoblasts transplanted into rat infarcted myocardium are functionally isolated from their host. Proc Natl Acad Sci USA 2003, 100:7808-78।I.

\section{Publish with Bio Med Central and every scientist can read your work free of charge}

"BioMed Central will be the most significant development for disseminating the results of biomedical research in our lifetime. "

Sir Paul Nurse, Cancer Research UK

Your research papers will be:

- available free of charge to the entire biomedical community

- peer reviewed and published immediately upon acceptance

- cited in PubMed and archived on PubMed Central

- yours - you keep the copyright

Submit your manuscript here:

http://www.biomedcentral.com/info/publishing_adv.asp
BioMedcentral 